\title{
TEORI PEMISAHAN KEKUASAAN DAN KONSTITUSI MENURUT NEGARA BARAT DAN ISLAM
}

\author{
SUPARTO \\ Fakultas Hukum Universitas Islam Riau \\ Jl. Kaharuddin Nasution 113 Marpoyan Damai Pekanbaru 24288 \\ Email : Suparto@law.uir.ac.id
}

\begin{abstract}
Separations of Powers theory had just been developed by John Locke and Montesquieu circa 17 A.C. Theory of Constitution had also just been emerged circa 18 A.C., even though in old Greece many people had already discussed about this theory. whereas Islam has recognized the separation of powers and constitutions long before that, namely when Rasulullah SAW rule Madinah and Madinah Constitution circa 7 A.C..

Keywords : Separations of Powers, Constitution
\end{abstract}

\begin{abstract}
ABSTRAK
Teori Pemisahan Kekuasaan yang dikembangkan oleh John Locke dan Montesquieu baru muncul sekitar abad ke 17, demikian juga dengan munculnya teori dan hukum Konstitusi baru berkembang sekitar abad ke 18, walaupun sebelumnya pada masa Yunani kuno Konstitusi telah banyak dibicarakan. Sedangkan Islam telah mengenal adanya Pemisahan Kekuasaan dan Konstitusi jauh sebelum itu yaitu pada masa pemerintahan Rasulullah SAW di Negara Madinah dan Konstitusi Madinah yaitu pada abad ke 7.
\end{abstract}

Kata kunci : Pemisahan Kekuasaan, Konstitusi 


\section{PENDAHULUAN}

Prinsip pemisahan kekuasaan dikembangkan oleh dua pemikir besar dari Inggris dan Perancis, John Locke dan Montesquieu. Konsep pemisahan kekuasaan yang dikemukakan oleh dua pemikir besar tersebut kemudian dikenal dengan teori Trias Politica. Menurut John Locke kekuasaan itu dibagi dalam tiga kekuasaan, yaitu : ${ }^{1}$

a. Kekuasaan legislatif, bertugas untuk membuat peraturan dan undangundang.

b. Kekuasaan eksekutif, bertugas untuk melaksanakan undang-undang yang ada di dalamnya termasuk kekuasaan untuk mengadili.

c. Kekuasaan federatif, tugasnya meliputi segala tindakan untuk menjaga keamanan negara dalam hubungan dengan negara lain seperti membuat aliansi dan sebagainya (dewasa ini disebut hubungan luar negeri).

Sementara itu Montesquieu dalam masalah pemisahan kekuasaan membedakannya dalam tiga bagian pula meskipun ada perbedaan dengan konsep yang disampaikan John Locke, yaitu :

a. Kekuasaan legislatif, bertugas untuk membuat undang-undang.

b. Kekuasaan eksekutif, bertugas untuk menyelenggarakan undang-undang (tetapi oleh Montesquieu diutamakan tindakan di bidang politik luar negeri).

c. Kekuasaan yudikatif, bertugas untuk mengadili atas pelanggaran undangundang.

Dari dua pendapat ini ada perbedaan pemikiran antara John Locke dengan Montesquieu. John Locke memasukkan kekuasaan yudikatif ke dalam kekuasaan eksekutif, sementara Montesquieu memandang kekuasaan pengadilan (yudikatif) itu sebagai kekuasaan yang berdiri sendiri. ${ }^{2}$ Menurut Montesquieu dalam setiap pemerintahan tiga jenis kekuasaan itu mesti terpisah satu sama lainnya, baik mengenai tugas (functie) maupun mengenai alat perlengkapan (organ) yang

\footnotetext{
${ }^{1}$ Miriam Budiardjo, 2002, Dasar-Dasar Ilmu Politik, (Jakarta : Gramedia), hlm .150.

${ }^{2}$ Ibid
} 
melakukannya. Menurut ajaran ini tidak dibenarkan adanya campur tangan atau pengaruh-mempengaruhi, antara yang satu dengan yang lainnya. Oleh karena itu ajaran Montesquieu disebut pemisahan kekuasaan artinya ketiga kekuasaan itu masing-masing harus terpisah baik lembaganya maupun orang yang menanganinya. ${ }^{3}$ Terkait dengan teori pemisahan, Montesquieu membuat analisis atas pemerintahan Inggris dan ia menyatakan ; ketika kekuasaan legislatif dan eksekutif disatukan pada orang yang sama, atau pada lembaga tinggi yang sama, maka tidak ada kebebasan. Sekali lagi tidak akan ada kebebasan, jika kekuasaan kehakiman tidak dipisahkan dari kekuasaan legislatif dan eksekutif. Dan pada akhirnya akan menjadi hal yang sangat menyedihkan bila orang yang sama atau lembaga yang sama menjalankan ketiga kekuasaan itu, yaitu menetapkan hukum, manjalankan keputusan-keputusan publik dan mengadili kejahatan atau perselisihan para individu. ${ }^{4}$

Adanya pemisahan kekuasaan dalam negara diatur dalam hukum dasar dari suatu negara yaitu Undang-Undang Dasar atau Konstitusi. Konstitusi atau UUD merupakan dokumen negara yang memuat hal-hal pokok penyelenggaraan negara. Moh. Mahfud MD berpendapat bahwa pada dasarnya konstitusi mengandung halhal sebagai berikut ; Pertama, public authority hanya dapat dilegitimasi menurut ketentuan konstitusi; Kedua, pelaksanaan kedaulatan rakyat (melalui perwakilan) harus dilakukan dengan menggunakan prinsip universal and equal suffrage dan pengangkatan eksekutif harus melalui pemilihan yang demokratis; Ketiga, adanya pemisahan atau pembagian kekuasaan serta pembatasan wewenang; Keempat, adanya kekuasaan kehakiman yang mandiri yang dapat menegakkan hukum dan keadilan baik terhadap rakyat maupun terhadap penguasa; Kelima, adanya sistem kontrol terhadap militer dan kepolisian untuk menegakkan hukum dan menghormati hak-hak rakyat; Keenam, adanya jaminan perlindungan atas HAM. ${ }^{5}$

\footnotetext{
${ }^{3}$ Moh. Kusnardi dan Harmaily Ibrahim, 1983, Pengantar Hukum Tata Negara Indonesia, (Jakarta : Pusat Studi Hukum Tata Negara Fakultas Hukum UI), hlm. 141.

${ }^{4}$ Baron de Montesquieu, tt, The Spirit of Laws ; Dasar-Dasar Ilmu Hukum dan Politik diterjemahkan oleh M. Khoiril Anam, (Bandung : Nusa Media), hlm. 62.

${ }^{5}$ Moh. Mahfud MD, 2000, Demokrasi dan Konstitusi Indonesia :Studi Tentang Interaksi Politik dan Kehidupan Ketatanegaraan, (Jakarta : Rineka Cipta), hlm. 421.
} 
Islampun juga mempunyai pemikiran tentang pentingnya pemisahan kekuasaan tersebut jauh sebelum dunia Barat (Eropa) menggagasnya, karena biasanya golongan yang memerintah sebagai pemegang kekuasaan, cenderung menyalahgunakan kekuasaannya, apalagi bila kekuasaan itu terkumpul dalam satu tangan atau badan sehingga diperlukan adanya pemisahan kekuasaan. Demikian juga dengan Konstitusi atau Undang-Undang Dasar, pada masa Negara Madinah sudah mempunyai Konstitusi yaitu Konstitusi Madinah. Dalam tulisan ini, penulis akan mengulas tentang Perbandingan Teori Pemisahan Kekuasaan dan Konstitusi menurut Negara Barat dan Islam.

\section{TEORI PEMISAHAN KEKUASAAN DAN KONSTITUSI MENURUT NEGARA BARAT DAN ISLAM}

\section{A. Teori Pemisahan Kekuasaan Menurut Negara Barat Dan Islam}

Teori pemisahan kekuasaan pertama kali dipopulerkan secara ilmiah oleh John Locke seorang filosof berkebangsaan Inggris (1632-1704) dalam bukunya Two Treatises of Government, yang terbit tahun 1690. John Locke membagi kekuasaan dalam Negara menjadi tiga yaitu : pertama, kekuasaan membentuk undang-undang (legislatif); kedua, kekuasaan melaksanakan undang-undang (eksekutif); dan ketiga, kekuasaan mengenai perang dan damai, membuat perserikatan dan aliansi serta segala tindakan dengan semua orang dan badanbadan di luar negari (federatif). ${ }^{6}$

Pemikiran ini lahir sebagai bentuk reaksi terhadap absolutisme dengan mendukung pembatasan kekuasaan politik raja. John Locke, berpendapat bahwa alasan mengapa manusia memasuki suatu "social contract" adalah untuk mempertahankan kehidupan, kebebasan dan hak untuk memiliki. Ketiga model

\footnotetext{
${ }^{6}$ Ismail Suny, 1982, Pembagian Kekuasaan Negara, (Jakarta : Aksara Baru), hlm. 1-2.
} 
dasar itu dipandang sebagai "milik" (property). Milik inilah yang memberikan kepada manusia status politik. ${ }^{7}$

Berkaitan dengan fungsi negara, John Locke membedakannya ke dalam empat fungsi. Keempat fungsi negara tersebut adalah pembentukan undangundang (legislating), membuat keputusan (judging), menggunakan kekuatan secara internal dalam melaksanakan undang-undang (employing forces internally in the execution of the laws) dan menggunakan kekuatan-kekuatan tersebut di luar negeri, dalam membela masyarakat. Locke menamakan fungsi pertama "legislative powers", fungsi ketiga dinamakan dengan "executive powers". Fungsi keempat disebutnya dengan "federative powers", yang meliputi kekuasaan perang dan damai serta kekuasaan luar negeri. Sedangkan fungsi kedua yaitu membuat keputusan (the function of judging) dianggapnya bukan sebagai kekuasaan. Oleh karena itu menurutnya tidak perlu mengindividualisir kekuasaan membuat keputusan (the powers of judging) secara tersendiri dalam bagian terpisah karena fungsi ini merupakan fungsi negara tradisional. Lebih lanjut John Locke beranggapan bahwa bila kekuasaan diletakkan pada tangan yang berbeda dapat dicapai suatu keseimbangan. ${ }^{8}$

Pemikiran John Locke, ternyata mempengaruhi ahli hukum Perancis bernama Montesquieu (1689-1755) untuk lebih menyempurnakan konsep pemisahan kekuasaan. Montesquieu dalam bukunya berjudul De L'Esprit des Lois terbit tahun 1748, mengemukakan teori pemisahan kekuasaan negara. Montesquieu menyatakan bahwa kekuasaan dalam negara harus dipisahkan dalam tiga kekuasaan, yaitu : pertama, kekuasaan legislatif (la puissance legislative) yang membentuk undang-undang; kedua, kekuasaan eksekutif (la puissance executive) yang melaksanakan undang-undang; dan ketiga, kekuasaan yudikatif (la puissance de juger), yang menjalankan kekuasaan kehakiman. ${ }^{9}$

\footnotetext{
${ }^{7}$ Brewer Carias dalam Efik Yusdiansyah, 2010, Implikasi Keberadaan Mahkamah Konstitusi Terhadap Pembentukan Hukum Nasional Dalam Kerangka Negara Hukum, (Bandung : Lubuk Agung), hlm. 24.

${ }^{8}$ Ibid., hlm. 24-25.

9 Ibid., hlm. 25.
} 
Islampun juga mempunyai pemikiran tentang pentingnya pemisahan kekuasaan tersebut jauh sebelum dunia Barat (Eropa) menggagasnya, karena biasanya golongan yang memerintah sebagai pemegang kekuasaan, cenderung menyalahgunakan kekuasaannya, apalagi bila kekuasaan itu terkumpul dalam satu tangan atau badan sehingga diperlukan adanya pemisahan kekuasaan.

Pada masa Rasulullah SAW sudah berada di Madinah, Allah SWT memberi isyarat tentang adanya fungsi-fungsi legislatif, eksekutif dan yudikatif di dalam suatu negara. Hal itu diisyaratkan oleh Allah SWT di dalam salah satu surah Madaniyyah yang berbunyi sebagai berikut:

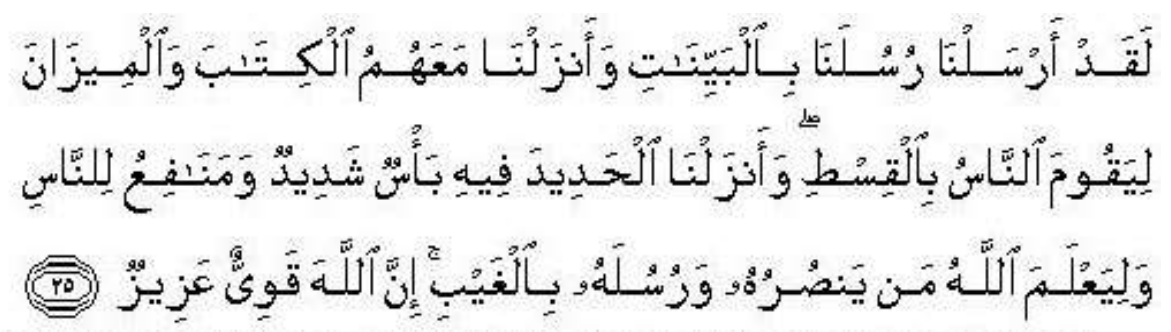

Sesungguhnya Kami telah mengutus rasul-rasul Kami dengan membawa buktibukti yang nyata dan telah Kami turunkan bersama mereka Al Kitab dan neraca (keadilan) supaya manusia dapat melaksanakan keadilan. Dan Kami ciptakan besi yang padanya terdapat kekuatan yang hebat dan berbagai manfaat bagi manusia, (supaya mereka mempergunakan besi itu) dan supaya Allah mengetahui siapa yang menolong (agama)Nya dan rasul-rasul-Nya padahal Allah tidak dilihatnya. Sesungguhnya Allah Maha Kuat lagi Maha Perkasa. (QS. Al-Hadiid $57: 25)$.

Menurut Muhammad Alim bahwa makna ayat diatas adalah, Rasulullah SAW yang tugasnya menyampaikan hukum-hukum Allah SWT melambangkan eksekutif, Al Kitab melambangkan perundang-undangan (legislatif), dan neraca melambangkan peradilan (yudikatif). ${ }^{10}$

${ }^{10}$ Muhammad Alim, 2008, Trias Politica Dalam Negara Madinah, (Jakarta : Sekretariat Jenderal dan Kepaniteraan Mahkamah Konstitusi RI), hlm. 62-63. 
Dalam piagam Madinah Nabi Muhammad SAW diakui sebagai pemimpin tertinggi yang berarti pemegang kekuasaan legislatif, eksekutif dan yudikatif. Tapi walaupun pada masa itu orang belum mengenal teori pemisahan atau pembagian kekuasaan, namun dalam prakteknya beliau mendelegasikan tugas-tugas eksekutif dan yudikatif kepada para sahabat yang dianggap cakap dan mampu.

Untuk pemerintahan di Madinah, Nabi menunjuk beberapa sahabat sebagai pembantu beliau, sebagai katib (sekretaris), sebagai amil (pengelola zakat) dan sebagai qadhi (hakim). Untuk pemerintahan di daerah, Nabi mengangkat seorang wali, seorang qadhi dan seorang amil untuk setiap daerah atau propinsi. Pada masa Rasulullah Negara Madinah terdiri dari sejumlah propinsi, yaitu Madinah, Tayma, al-Janad, daerah Banu Kindah, Mekkah, Naj-ran, Yaman, Hadramaut, Oman dan Bahrain. Masing-masing pejabat memiliki kewenangan sendiri dalam melaksanakan tugasnya. Seorang qadhi diberi beberapa kebebasan penuh dalam memutuskan setiap perkara, karena secara struktural ia tidak berada di bawah wali. Ali bin Abi Thalib dan Muaz bin Jabal adalah dua orang qadhi yang diangkat Nabi, yang bertugas di dua propinsi berbeda. ${ }^{11}$

Terkait dengan pemisahan kekuasaan menurut Islam dalam arti secara horizontal, hal tersebut sudah dilaksanakan yaitu ketika Negara Madinah dipimpin oleh Umar bin Khattab. Dalam rangka pemencaran kekuasaan ia menyerahkan kekuasaan Yudikatif kepada pejabat lain. Untuk itu diangkatlah para hakim yang diberi gelar Qadi. Untuk hakim di Madinah diangkat Abu ad Darba, untuk Kufah diangkat Syuraih, di Basrah bertugas Abu Musa al Asy'ari dan setelah Mesir dibebaskan oleh tentara Islam Madinah maka diangkatlah Qais bin al As Sahmi sebagai hakim di sana. Para hakim yang diangkat oleh Umar bin Khattab bebas memutuskan perkara dalam batas-batas Kitabullah dan Sunah Rasulullah SAW

${ }^{11}$ Muhammad A. Al-Burey, 1986, Islam Landasan Alternatif Administrasi Pembangunan, (Jakarta : Rajawali Pers), hal. 254-255 dikutip J. Suyuti Pulungan, 1999, Fiqh Siyasah ; Ajaran, Sejarah dan Pemikiran, (Jakarta : Raja Grafindo Persada), hlm. 97-98. 
atau syariah. Dengan pengangkatan para hakim untuk mengadili perkara berarti kekuasaan yudikatif tidak lagi seluruhnya menyatu dengan kekuasaan eksekutif. ${ }^{12}$

Sementara itu, dalam Negara Madinah telah ada institusi yang disebut Majelis Syura atau Majelis Sahabat atau Majelis Syuyukh yang anggotaanggotanya terdiri dari para pemuka sahabat, para pemuka rakyat di ibukota Madinah dan para kepala kabilah atau kepala suku. Majelis inilah yang menjadi semacam dewan perwakilan rakyat atau parlemen dalam Negara Madinah. Namun demikian Majelis ini belum berfungsi sebagaimana lazimnya parlemen yaitu membuat undang-undang. ${ }^{13}$ Berdasarkan uraian-uraian diatas maka dalam praktik, bukan lagi dalam tataran teori, Negara Madinah pada masa pemerintahan Umar bin Khattab (634-644) telah melakukan pembagian kekuasaan secara horizontal. Telah ada lembaga eksekutif yaitu Khalifah dan stafnya, ada lembaga legislatif yakni yang disebut Majelis Syura sebagai Dewan Perwakilan Rakyat yang dikemudian hari untuk otoritas menetapkan hukum dilakukan oleh ahl al hall wa al aqd, bersama-sama dengan Khalifah dan juga sudah ada lembaga yudikatif yang dilakukan oleh para hakim atau Qadi. Adapun pembagian kekuasaan secara vertikal pada zaman Rasulullah SAW masih hidup beliau telah membagi kekuasaan antara pemerintah pusat dan daerah, yakni dengan para Gubernur. ${ }^{14}$

\section{B. Teori Konstitusi Menurut Negara Barat Dan Islam}

Dalam Ilmu Negara dan Hukum Tata Negara, Konstitusi diberi arti yang berubah-ubah sejalan dengan perkembangan kedua ilmu tersebut. Pertama, pengertian konstitusi pada masa pemerintahan-pemerintahan kuno (ancient regime). Kedua, pengertian konstitusi menurut tafsiran modern yakni sejak kelahiran dokumen konstitusi pertama di dunia yang dikenal dengan nama Virginia Bill of Rights (1776). ${ }^{15}$

${ }^{12}$ Ibid., hlm. 91.

${ }^{13}$ Abdul Qadim Zallum, 2002, Sistem Pemerintahan Islam, Diterjemahkan oleh M. Maghfur W, (Bangil : Al-Izzah), hlm. 280-281.

${ }^{14}$ Muhammad Alim, 2009, Konstitusi Negara Dalam Perspektif Islam, (Jakarta : Mahkamah Konstitusi Republik Indonesia), hlm. 85-88.

${ }^{15}$ Ubaidillah A dkk, 2000, Pendidikan Kewarganegaraan Demokrasi, HAM dan Masyarakat Madani, (Jakarta : IAIN Jakarta Press), hlm. 82. 
K.C. Wheare mengartikan konstitusi sebagai keseluruhan sistem ketatanegaraan dari suatu negara berupa kumpulan peraturan-peraturan yang membentuk, mengatur atau memerintah dalam pemerintahan suatu negara. Peraturan disini merupakan gabungan antara ketentuan-ketentuan yang memiliki sifat hukum (legal) dan yang tidak memiliki sifat hukum (non legal). ${ }^{16}$

Sementara itu istilah UUD merupakan terjemahan dari perkataan Belanda Grondwet. Dalam kepustakaan Belanda, selain Grondwet juga digunakan istilah Constitutie. Kedua istilah tersebut mempunyai pengertian yang sama. ${ }^{17}$

Undang-Undang Dasar sebagai konstitusi tertulis beserta nilai-nilai dan norma hukum dasar tidak tertulis yang hidup sebagai konvensi ketatanegaraan dalam praktek penyelenggaraan negara sehari-hari, termasuk ke dalam pengertian konstitusi atau hukum dasar (droit constitusionnel) suatu negara. ${ }^{18}$

Pada umumnya para pakar hukum tata negara di Indonesia berpendapat bahwa konstitusi sama dengan Undang-Undang Dasar, seperti Sri Soemantri, G.L. Wolhoff, Usep Ranawidjaja, dll. Konstitusi dapat digunakan dalam dua arti. Pertama, untuk menunjuk seluruh ketentuan yang mengatur organisasi negara. Kedua, untuk menunjuk satu atau beberapa dokumen yang memuat ketentuanketentuan pokok tentang organisasi negara. ${ }^{19}$

Menurut Sri Soemantri istilah Konstitusi berasal dari perkataan constitution. ${ }^{20}$ Dalam bahasa Indonesia dijumpai istilah hukum yang lain, yaitu

\footnotetext{
${ }^{16}$ Dahlan Thaib, Jazim Hamidi \& Ni'matul Huda, 2006, Teori dan Hukum Konstitusi, (Jakarta : Raja Grafindo Persada), hlm. 13.

${ }^{17}$ Sri Soemantri, UUD 1945 Kedudukan dan Artinya dalam Kehidupan Bernegara, Jurnal Demokrasi \& HAM, Vol.1 No.4, September-Nopember 2001, hlm. 47.

${ }^{18}$ Jimly Asshiddiqie, 2005, Konstitusi dan Konstitusionalisme Indonesia, (Jakarta : Konpress, Mahkamah Konstitusi Republik Indonesia), hal. 35. Lihat juga Bagir Manan, 1995, Pertumbuhan dan Perkembangan Konstitusi Suatu Negara, (Bandung : Mandar Maju), hlm. 5-6.

${ }^{19}$ Iriyanto A. Baso Ence, 2008, Negara Hukum dan Hak Uji Konstitusionalitas Mahkamah Konstitusi (Telaah Terhadap Kewenangan Mahkamah Konstitusi), (Bandung : Alumni), hlm. 20.

${ }^{20}$ Menurut Rukmana Amanwinata dalam Ellydar Chaidir, Hukum dan Teori Konstitusi, 2007, (Yogyakarta : Kreasi Total Media), hal. 20-21. Istilah "konstitusi" dalam bahasa Indonesia antara lain berpadanan dengan kata "constitution" (bahasa Inggris), "constitutie" (bahasa Belanda), "constitutionel" (bahasa Perancis), "Verfassung" (bahasa Jerman), "constitutio" (bahasa Latin) dan Fundamental Laws (Amerika Serikat). Istilah konstitusi menurut Wirjono Prodjodikoro dalam Bukunya Asas-Asas Hukum Tata Negara Indonesia, Dian Rakyat, Jakarta, 1989. hlm. 10. Berasal dari kata kerja "constituer" (Perancis) yang berarti membentuk, jadi
} 
undang-undang dasar dan/atau hukum dasar. Dalam perkembangannya istilah konstitusi mempunyai dua pengertian, yaitu pengertian yang luas dan pengertian yang sempit. ${ }^{21}$ Konstitusi (atau UUD) merupakan hukum dasar yang menjadi pegangan para warga (the citizen) dalam kehidupan bermasyarakat dan bernegara. Konstitusi tidak hanya memuat norma tertinggi (een hoogste normen) tetapi merupakan pula pedoman konstitusional (een constitutionale richtsnoer) bagi para warga negara. ${ }^{22}$

Sri Soemantri menyebutkan bahwa pada umumnya konstitusi sebagai hukum dasar berisi 3 hal pokok :

(1)Adanya jaminan terhadap hak-hak asasi manusia dan warga negara

(2)Ditetapkannya susunan ketatanegaraan yang bersifat fundamental

(3)Adanya pembagian dan pembatasan tugas ketatanegaraan yang juga bersifat fundamental. ${ }^{23}$

Jauh sebelum pemikir-pemikir Barat mengemukakan kemauan mereka atas berbagai konstitusi di Yunani, sejarah Islam telah mencatat bahwa sejak zaman Rasulullah, telah lahir konstitusi tertulis yang pertama, yang kemudian dikenal dengan Konstitusi Madinah atau ada juga yang menyebut sebagai Piagam Madinah. Sejarah menunjukkan bahwa Nabi Muhammad SAW. dan umat Islam selama kurang lebih 13 tahun di Mekah terhitung sejak pengangkatan Muhammad SAW. sebagai Rosul, belum mempunyai kekuatan dan kesatuan politik yang menguasai suatu wilayah. Umat Islam menjadi komunitas yang bebas dan

konstitusi berarti pembentukan. Dalam hal ini yang dibentuk adalah suatu negara, maka konstitusi mengandung permulaan dari segala peraturan mengenai suatu negara.

${ }^{21}$ Sri Soemantri dalam Sumbodo Tikok, 1992, Hukum Tata Negara, (Bandung : Eresco), hlm. 115-116. Lihat juga dalam Ellydar Chaidir, 2008, Sistem Pemerintahan Negara RI Pasca Perubahan UUD 1945, (Yogyakarta : Total Media), hal. 102. Perhatikan juga dalam Moh. Kusnardi dan Harmaily Ibrahim, Op.Cit., hlm.64. disebutkan bahwa Konstitusi berasal dari istilah constitution (Bhs. Inggris), constitutio (Bahasa Latin) atau Verfassung (Bahasa Belanda) memiliki perbedaan dari undang-undang dasar Grundgesetz. Jika ada kesamaan itu merupakan kekhilafan pandangan di Negara-negara modern. Kekhilafan tersebut disebabkan oleh pengaruh paham kodifikasi yang menghendaki setiap peraturan harus tertulis, demi mencapai kesatuan hukum, kesederhanaan hukum dan kepastian hukum.

${ }^{22}$ H. M. Laica Marzuki, Kesadaran Berkonstitusi dalam Kaitan Konstitusionalisme, Jurnal Konstitusi Mahkamah Konstitusi R I, Volume 6, Nomor 3, September 2009

${ }^{23}$ Sri Soemantri dalam Astim Riyanto, Hukum Konstitusi Sebagai Suatu Ilmu, Jurnal Hukum dan Pembangunan, Tahun ke 39 No.1 Januari - Maret 2009. 
merdeka setelah pada tahun 622 M hijrah ke Madinah, kota yang sebelumnya disebut Yasrib. ${ }^{24}$

Tidak lama sesudah hijrah ke Madinah, Muhammad SAW. membuat suatu piagam politik untuk mengatur kehidupan bersama di Madinah yang dihuni oleh berbagai macam golongan. ${ }^{25}$ Ia memandang perlu meletakkan aturan pokok tata kehidupan bersama di Madinah, agar terbentuk kesatuan hidup diantara seluruh penghuninya. Di tengah kemajemukan penghuni kota Madinah itu, Muhammad SAW. berusaha membangun tatanan hidup bersama, mencakup semua golongan yang ada di kota Madinah. Sebagai langkah awal ia 'mempersaudarakan' antara para Muslim pandatang dan Muslim Madinah. Persaudaraan itu bukan hanya tolong menolong dalam kehidupan sehari-hari, tetapi demikian mendalam sampai ke tingkat mewarisi. Kemudian diadakan perjanjian hidup bersama secara damai diantara berbagai golongan yang ada di Madinah, baik diantara golongangolongan Islam, maupun dengan golongan-golongan Yahudi itu, secara formal ditulis dalam suatu naskah yang disebut Shahifah. Kesatuan hidup yang baru dibentuk itu dipimpin oleh Muhammad SAW. sendiri dan menjadi Negara berdaulat. Dengan demikian, di Madinah Nabi Muhammad SAW. bukan hanya mempunyai sifat Rosul Allah, tetapi juga mempunyai sifat Kepala Negara. ${ }^{26}$

Ditetapkannya piagam tersebut merupakan salah satu siasat Rosul sesudah hijrah ke Madinah, yang dimaksudkan untuk membina kesatuan hidup berbagai

${ }^{24}$ Ni’matul Huda, 2007, Lembaga Negara dalam Masa Transisi Demokrasi, (Yogyakarta : UII Press) hlm. 1. Lihat juga dalam Munawir Sjazali, 2003, Islam dan Tata Negara; Ajaran, Sejarah dan Pemikiran, Edisi Kelima, (Jakarta : UI Press), hlm. 9.

${ }^{25}$ Muhammad Jamal al-Din Surur,1997, Qiyam al-Dawlah al Arabiyah al Islamiyah fi Hayati Muhammad SAW, (Al Qahirah : Dar al Fikr al Araby), hal. 95 dikutip oleh Ahmad Sukardja, 1995, Piagam Madinah dan Undang-Undang Dasar 1945, (Jakarta : UI Press), hal. 2. Sebagaimana diketahui bahwa penduduk Madinah terdiri dari tiga golongan besar, yaitu Muslimin, Musyrikin dan Yahudi. Muslimin terdiri dari golongan Muhajirin dan Anshar. Golongan Muhajirin adalah pendatang yang hijrah dari Mekah. Mereka adalah orang-orang Quraysi yang telah masuk Islam yang terdiri dari beberapa kelompok, diantaranya Banu Hasyim dan Banu Muthalib. Kabilah 'Aws dan Khazraj merupakan unsur utama golongan Anshar yang masing-masing terdiri dari kelompok-kelompok suku yang banyak. Golongan Musrykin adalah orang-orang Arab yang masih menyembah berhala (paganisme). Golongan Yahudi terdiri dari keturunan Yahudi, pendatang dan keturunan Arab yang masuk agama Yahudi atau kawin dengan orang Yahudi pendatang. Tiga kelompok besar keturunan Yahudi pendatang adalah Banu Nadir, Banu Qaynuqa dan Banu Qurayshah.

${ }^{26}$ Harun Nasution, 1985, Islam Ditinjau dari Berbagai Aspeknya, (Jakarta : Universitas Indonesia Press), Cetakan kelima, hlm. 92. 
golongan warga Madinah. Dalam piagam tersebut dirumuskan kebebasan beragama, hubungan antar kelompok, kewajiban mempertahankan kesatuan hidup, dan lain-lain. Berdasarkan isi Piagam Madinah itulah warga Madinah yang majemuk, secara politis dibina dibawah pimpinan Muhammad SAW. Dalam berbagai tulisan yang disusun oleh para ilmuwan muslim dan non muslim, adanya Piagam Madinah itu tampaknya telah diakui W. Montgomery Watt menyatakan bahwa "dokumen ini secara umum diakui autentik". Ia menambahkan dokumen tersebut merupakan sumber ide yang mendasari negara Islam pada awal pembentukannya. $^{27}$

Apakah Shahifah atau Piagam Madinah telah memenuhi syarat untuk disebut konstitusi, Marduke Pickthal, H.A.R. Gibb, Wensinck, dan Watt menyebut Shahifah sebagai konstitusi. ${ }^{28}$ Namun, masih perlu dikaji lebih jauh apakah Shahifah memenuhi syarat untuk sebuah konstitusi.

Pada umumnya konstitusi suatu negara adalah hukum tertinggi dalam negara tersebut. Mengacu kepada konstitusi sebagai hukum tertinggi, maka Al Quran sebagai hukum tertinggi dalam tata urutan Hukum Islam, adalah konstitusi. Sebelum tahun 1992, Undang-Undang Dasar Arab Saudi adalah Al Quran dan Sunnah Rasulullah SAW (syariah). Tahun 1992 Arab Saudi melakukan reformasi sekaligus mengumumkan Undang-Undang Dasar (Basic Law). Seperti halnya di Arab Saudi, Ahmad Azhar Basyir dan Moh Mahfud MD berpendapat bahwa Konstitusi Islam itu adalah Al Quran dan Sunnah, maka Piagam Madinah yang dibuat oleh Rasulullah SAW pada Tahun 1 H (622 M) merupakan pula bagian dari Konstitusi Islam. $^{29}$

Kalau dibandingkan dengan Konstitusi sebagai hukum tertinggi dalam suatu negara misalnya di Indonesia dan Amerika serikat yang menetapkan konstitusinya sebagai konstitusi derajat tinggi (supreme constitution), maka dalam Negara Madinah sebagai negara Islam, sumber-sumber hukumnya, termasuk sumber hukum konstitusinya berurut dari yang tertinggi adalah (1) Al Quran, (2) Al

\footnotetext{
${ }^{27}$ Ahmad Sukardja, Piagam Madinah....Op. Cit., hlm. 35.

${ }^{28}$ J. Suyuti Pulungan, 1994, Prinsip-prinsip Pemerintahan Dalam Piagam Madinah Ditinjau dari Pandangan Al Quran, (Jakarta : Raja Grafindo Persada), hlm. 115.

${ }^{29}$ Muhammad Alim, 2009, Konstitusi Negara...Op.Cit., , hlm. 25.
} 
Sunnah, (3) Konvensi-konvensi Khulafa ur Rasyidin dan (4) Ketentuan para ahli hukum (fukaha) ternama. Khalid Ibrahim Jindan sebagaimana dikutip Muhammad Alim juga menulis bahwa Al Quran, Al Sunnah dan praktek kehidupan $A l$ Khulafa' ar Rasyidun adalah sumber Konstitusi Islam. Sejalan dengan hal tersebut Abdul Wahab Khallaf sebagaimana dikutip Muhammad Alim berpendapat bahwa Konstitusi dalam Negara Islam adalah Al Quran dan Hadist Sahih. ${ }^{30}$

Berdasarkan uraian tersebut, penulis berpendapat bahwa Konstitusi Madinah adalah bagian dari Konstitusi Islam, karena kalau dilihat dari segi substansinya telah memenuhi syarat-syarat dari sebuah Konstitusi akan tetapi masih ada Konstitusi Islam yang merupakan hukum tertinggi yaitu Al-Qur'an dan Hadist.

\section{PENUTUP}

Teori pemisahan kekuasaan pertama kali dipopulerkan secara ilmiah oleh John Locke seorang filosof berkebangsaan Inggris (1632-1704) dalam bukunya Two Treatises of Government, yang terbit tahun 1690. John Locke membagi kekuasaan dalam Negara menjadi tiga yaitu : pertama, kekuasaan membentuk undang-undang (legislatif); kedua, kekuasaan melaksanakan undang-undang (eksekutif); dan ketiga, kekuasaan mengenai perang dan damai, membuat perserikatan dan aliansi serta segala tindakan dengan semua orang dan badanbadan di luar negari (federatif). Pemikiran John Locke, ternyata mempengaruhi ahli hukum Perancis bernama Montesquieu (1689-1755) untuk lebih menyempurnakan konsep pemisahan kekuasaan. Montesquieu dalam bukunya berjudul De L'Esprit des Lois terbit tahun 1748, mengemukakan teori pemisahan kekuasaan negara. Montesquieu menyatakan bahwa kekuasaan dalam negara harus dipisahkan dalam tiga kekuasaan, yaitu : pertama, kekuasaan legislatif (la puissance legislative) yang membentuk undang-undang; kedua, kekuasaan eksekutif (la puissance executive) yang melaksanakan undang-undang; dan ketiga,

\footnotetext{
${ }^{30}$ Ibid., hlm. 28-29.
} 
kekuasaan yudikatif (la puissance de juger), yang menjalankan kekuasaan kehakiman.

Dalam piagam Madinah Nabi Muhammad SAW diakui sebagai pemimpin tertinggi yang berarti pemegang kekuasaan legislatif, eksekutif dan yudikatif. Tapi walaupun pada masa itu orang belum mengenal teori pemisahan atau pembagian kekuasaan, namun dalam prakteknya beliau telah menjalankannya yaitu dengan cara mendelegasikan tugas-tugas legislatif, eksekutif dan yudikatif kepada para sahabat yang dianggap cakap dan mampu. Dibidang peradilan (yudikatif) di dunia Islam, sudah ada sejak negara Madinah. Pada masa-masa awal Islam, kekuasaan institusi peradilan dengan kompetensi masing-masing dapat dibagi atas tiga macam, yaitu : Pertama, pengadilan yang dipimpin oleh Qadi yang kompetensinya meyelesaikan perkara-perkara perdata. Kedua, pengadilan yang dipimpin Muhtasib (pengawas) yang berwenang mengadili urusan-urusan umum, urusan pidana (jinayat) uqubah, dan sebagainya. Dalam urusan perkara pidana, biasanya perkara yang kecil-kecil seperti penganiayaan dan sebagainya. Ketiga, Pengadilan yang dipimpin oleh Khalifah atau Gubernur yaitu mengadili perkara pidana yang berat, apalagi yang dilakukan oleh keluarga pejabat atau pejabat pemerintahan, majelisnya dipimpin oleh Khalifah atau Gubernur.

Teori Pemisahan Kekuasaan yang dikembangkan oleh John Locke dan Montesquieu baru muncul sekitar abad ke 17 dan 18 yaitu dengan diterbitkannya buku Two Treatises of Government tahun 1690 (John Locke) dan buku De L' Esprit des Lois yang terbit tahun 1748 (Montesquieu), dan pada intinya menyebutkan bahwa kekuasaan dalam negara harus dipisahkan dalam tiga kekuasaan. Selain dipisah, kekuasaan negara itu harus dibatasi, pemisahan dan pembatasan kekuasaan negara biasanya diatur dalam hukum dasar dari suatu negara yaitu Undang-Undang Dasar atau Konstitusi. Konstitusi atau UndangUndang Dasar merupakan dokumen negara yang memuat hal-hal pokok penyelenggaraan negara. Konstitusi tertulis didunia baru berkembang sekitar abad ke 18, walaupun sebelumnya pada masa Yunani Kuno, konstitusi telah banyak dibicarakan. 
Sedangkan Islam sendiri telah mengenal adanya Pemisahan Kekuasaan dan Konstitusi jauh sebelum dunia barat (eropa) mempopulerkannya, yaitu pada awal abad ke 7 ketika masa pemerintahan Rasulullah Muhammad SAW di Negara Madinah.

\section{Daftar Pustaka}

\section{A. Buku}

Alim, Muhammad, (2008), Trias Politica Dalam Negara Madinah, Jakarta : Sekretariat Jenderal dan Kepaniteraan Mahkamah Konstitusi RI.

Alim, Muhammad, (2009), Konstitusi Negara Dalam Perspektif Islam, Jakarta : Mahkamah Konstitusi Republik Indonesia.

Asshiddiqie, Jimly, (2005), Konstitusi dan Konstitusionalisme Indonesia, Jakarta : Konpress Mahkamah Konstitusi Republik Indonesia.

Budiardjo, Miriam, (2002), Dasar-Dasar Ilmu Politik, Jakarta : Gramedia.

Chaidir, Ellydar, (2007), Hukum dan Teori Konstitusi, Yogyakarta : Kreasi Total Media.

De Montesquieu, Baron, tt, The Spirit of Laws; Dasar-Dasar Ilmu Hukum dan Politik (diterjemahkan oleh M. Khoiril Anam), Bandung : Nusa Media.

Ence, Iriyanto A. Baso, (2008), Negara Hukum dan Hak Uji Konstitusionalitas Mahkamah Konstitusi (Telaah Terhadap Kewenangan Mahkamah Konstitusi), Bandung : Alumni.

Huda, Ni'matul, (2007), Lembaga Negara dalam Masa Transisi Demokrasi, Yogyakarta : UII Press.

Kusnardi, Moh., \& Harmaily Ibrahim, (1983), Pengantar Hukum Tata Negara Indonesia, Jakarta : Pusat Studi Hukum Tata Negara Fakultas Hukum UI.

Manan, Bagir, (1995), Pertumbuhan dan Perkembangan Konstitusi Suatu Negara, Bandung : Mandar Maju.

Mahfud MD, Moh., (2000), Demokrasi dan Konstitusi Indonesia : Studi tentang Interaksi Politik dan Kehidupan Ketatanegaraan, Jakarta : Rineka Cipta.

Nasution, Harun, (1985), Islam Ditinjau dari Berbagai Aspeknya, Jakarta : Universitas Indonesia Press, Cetakan kelima. 
Pulungan, Suyuti J., (1994), Prinsip-prinsip Pemerintahan Dalam Piagam Madinah Ditinjau dari Pandangan Al Quran, Jakarta : Raja Grafindo Persada.

-, (1999), Fiqh Siyasah ; Ajaran, Sejarah dan Pemikiran, Jakarta : Raja Grafindo Persada.

Sjazali, Munawir, (2003), Islam dan Tata Negara; Ajaran, Sejarah dan Pemikiran, Edisi Kelima, Jakarta : UI Press.

Sukardja, Ahmad, (1995), Piagam Madinah dan Undang-Undang Dasar 1945, Jakarta : UI Press.

Suny, Ismail, (1982), Pembagian Kekuasaan Negara, Jakarta : Aksara Baru

Thaib, Dahlan, Jazim Hamidi dan Ni'matul Huda, (2006), Teori dan Hukum Konstitusi, Jakarta : Raja Grafindo Persada.

Tikok, Sumbodo, (1992), Hukum Tata Negara, Bandung : Eresco.

Ubaidillah A dkk, (2000), Pendidikan Kewarganegaraan Demokrasi, HAM, \&Masyarakat Madani, Jakarta : IAIN Jakarta Press.

Yusdiansyah, Efik, (2010), Implikasi Keberadaan Mahkamah Konstitusi Terhadap Pembentukan Hukum Nasional Dalam Kerangka Negara Hukum, Bandung : Lubuk Agung.

Zallum, Abdul Qadim, (2002), Sistem Pemerintahan Islam, Diterjemahkan oleh M. Maghfur W., Bangil : Al-Izzah.

\section{B. Jurnal, Makalah}

Marzuki, H. M.Laica, Kesadaran Berkonstitusi dalam Kaitan Konstitusionalisme, Jurnal Konstitusi Mahkamah Konstitusi R I, Volume 6, Nomor 3, September 2009

Riyanto, Astim, Hukum Konstitusi Sebagai Suatu Ilmu, Jurnal Hukum dan Pembangunan Tahun ke 39 No.1 Januari - Maret 2009.

Soemantri, Sri, UUD 1945 Kedudukan dan Artinya dalam Kehidupan Bernegara, Jurnal Demokrasi \& HAM, Vol.1 No.4, September-Nopember 2001. 